\title{
ECONOMIC ANALYSIS AND PATTERN OF AGROCHEMICALS USE AMONG SMALLHOLDER CROP FARMERS IN EDU LOCAL GOVERNMENT AREA OF KWARA STATE
}

\author{
Adedeji Sharafadeen Olayinka ${ }^{1 凶}$, Alimi Folorunsho Lawal ${ }^{1}$, Madu Ali Bwala ${ }^{1}$, \\ Umaru Habiba Mohammed ${ }^{1}$, Ajao Ibrahim Sulaiman ${ }^{2}$ \\ 'Ibrahim Badamasi Babangida University, Nigeria \\ ${ }^{2}$ Federal College of Education (Special), Nigeria
}

\begin{abstract}
This study addresses the economic analysis and pattern of agrochemicals use among smallholder crop farmers in Edu Local Government Area of Kwara State, Nigeria. A multistage random sampling technique was used to select 144 small-scale crop farmers interviewed for the study. Descriptive statistics and farm budgeting techniques were used for data analysis. The result shows that a typical small-scale crop farmer in the study area is, on average, a 31-year-old male with 11 to 20 years of farming experience. These groups of farmers also cultivate 0.78 hectares and have a household size of 8 . Herbicides are the predominant agrochemical used during the survey; it was mostly applied both before and after crop emergence. Usually, pesticides were applied without following safety instructions. Users of agrochemicals obtained a total gross margin of USD 1,469.95 per hectare with a profitability ratio of 1.22 which indicates that farming is a profitable business in the study area. The study recommends to increase awareness on farmer safety measures when handling agrochemicals; and to establish educational programs that will educate farmers on how to safely use agrochemicals.
\end{abstract}

Keywords: Edu, agrochemicals, profitability ratio, gross margin, Nigeria, pesticides

\section{INTRODUCTION}

Hand-weeding is the predominant weed control practice on smallholder farms in Africa (Vissoh et al., 2004).
This method of controlling weeds is less expensive but tedious in operation. The time-consuming and stress aspect of hand-weeding necessitate the introduction of agrochemical as a labor saver and a less-time consuming means of weed control.

Agrochemical (agrichemical) is the term used when referring to the numerous chemical products used in agriculture. Agrochemicals often refer to a broad range of pesticides, such as fungicides, herbicides and insecticides. According to Larry (2012), the term can also be used when referring to hormones, fertilizers and other chemical growth agents and concentrated stores of raw animal manure. Agrochemicals like neem, wood ash etc. can be prepared locally by farmers while others are manufactured industrially in accordance with a series of procedures. Agrochemicals are mostly used in agriculture, especially in crop production based on the old system which uses organic manures to provide nutrients to crops for high yielding over a long period (Albert, 1989).

However, in this paper, the term pesticides is used synonymously with agrochemicals. There are many different types of pesticides, including herbicides used to kill or inhibit the growth of weeds; fungicides used to control fungal; insecticides to control insects; molluscicides to control molluscs; ovicide to control eggs of insects and mites; rodenticides to control rodents;

$\bowtie$ Adedeji Sharafadeen Olayinka, Msc, Department of Agricultural Economics and Extension Services, Ibrahim Badamasi Babangida University, Lapai, Niger State, Nigeria, e-mail: soadedeji@ibbu.edu.ng, https://orcid.org/0000-0002-1218-0067 

cals use among smallholder crop farmers in Edu Local Government Area of Kwara State. J. Agribus. Rural Dev., 2(52), 157-163. http://dx.doi.org/10.17306/J.JARD.2019.01161

mothball to control fabric pests; and disinfectants to control germs.

Agrochemicals are expensive and harmful to the health of both humans and soil. This hinders their adoption by small farmers. WHO (2008) also reported that most agrochemicals are toxic and can endanger human health. Hence, their use is highly regulated worldwide with provisions and conventions. Any abuse of these chemicals through improper storage or usage can result in losses.

In addition to the aforementioned effects of agrochemicals, Fleisher (2006) reported that the excessive use of chemical fertilizers in developing countries often receives less attention than the uses of pesticides. The economic and ecological impacts can be dramatic. The farmers significantly loss topsoil fertility due to excessive use of chemical fertilizers and pesticides. Meanwhile, pesticides are used in plant production, animal husbandry and public health programs. The methods and parameters for measuring their efficiency or cost differ greatly. Andrew (2008) reports that the use of some agrochemicals is associated with certain ecological damages. For example, an excessive use of fertilizers may lead to contamination of groundwater with nitrates which renders it unfit for consumption by livestock and humans. More so, the run-off of agricultural fertilizers into lakes, streams and other surface water can cause eutrophication (an increase in productivity of those aquatic ecosystems). Many users of agrochemicals have little knowledge about the dangers involved, and hence end up in tasting to determine their potency and ignoring the safety measures when formatting or applying them. Due to frequent application of these chemicals, many pests had their natural enemies destroyed and others have developed resistance strains. As a consequence, the fertility status of farmland is falling year in year out.

Agrochemicals become rampart and common as it is being used by all categories of farmers in almost all localities. Agrochemicals make pests management easy and timely, it can as well proffer solution to poor soil fertility. For most small-scale farmers, this is a major problem which results from a continuous use of the same piece of land and human economic and noneconomic activities (Larry, 2012). Meanwhile, according to WHO (2008), the use of these chemicals could do more harm than good if they are not handled with care; agrochemicals are toxic and dangerous to health of both human and soils. The outputs produced through these chemicals can pose dangers on humans and livestock that feeds them. Water around the environment where agrochemicals are used can be poisoned which is a threat to aquatic lives. According to Seattle (2008), the farmers are confronted over the years with a problem of low yield as a result of poor performance of soil and random use of agrochemicals. It is important to examine the pattern of agrochemicals used, the economic benefit to the users and the effect it has on the crop output level of small-scale users. Therefore, this research is set out to assess how well agrochemicals are being used by small farmers. It is against these backdrops that this paper examines the pattern and economic analysis of pesticide use among smallholder crop farmers in the study area. To achieve the above objective, this study describes the socioeconomic characteristics of smallholder crop farmers; examines the pattern of pesticide inputs used by small-scale crop farmers; analyzes the economic benefits derived from crops grown as a result of using agrochemicals; and examines the output level achieved by agrochemical users.

\section{MATERIAL AND METHODS}

This study was carried out in Edu Local Government Area of Kwara State, Nigeria which has three districts, namely: Tsaragi, Tsonga and Lafiagi. The headquarters of the Local Government are located at Lafiagi, about $105 \mathrm{~km}$ east of Ilorin, the Kwara State capital. It is bordered by Moro, Patigi and Ifelodun Local Government Areas of Kwara State and Mokwa Local Government Area of Niger State. The entire area is located in the North Central region of Nigeria, with a population of about 25,349 (2006 NPC). The area observes distinct wet and dry seasons with a mean annual rainfall of 1,000 to $1,500 \mathrm{~mm}$. The climate, soil type and hydrology allow the growing of most of staple crops and still leave large areas for fresh water fisheries and grazing, especially in Lafiagi and Tsonga districts. Farming is the main occupation of the inhabitants of Edu Local Government Area

\section{Sampling techniques}

The population covered by this study are small-scale arable crop farmers in Edu Local Government Area, Kwara State who cultivate four types of farm crops, namely: millet, maize, rice and cowpea. Some of these crop farmers do grow the crops either in a mixed cropping 

cals use among smallholder crop farmers in Edu Local Government Area of Kwara State. J. Agribus. Rural Dev., 2(52), $157-163$. http://dx.doi.org/10.17306/J.JARD.2019.01161

system or a mono-cropping system. A multistage sampling technique was employed to select respondents for the study. The first stage involves the random selection of two out of the three districts in the local governments; at this stage, Tsaragi and Tsonga districts were selected for the study in the Local Government Area. At the second stage of sampling, two wards were randomly selected from each of the selected districts while four villages were randomly selected from each of the selected wards at the third stage of sampling for the study. A total of sixteen villages were selected. In each village, the author (accompanied by enumerators) randomly selected nine small-scale crop farmers from the list of farmers prepared during the field visits. The total number of respondents used for the study was 144 small-scale crop farmers who cultivate four major crop types under consideration. The main instrument for data collection was structured questionnaire.

\section{Analytical techniques}

Combinations of analytical techniques were used for the study, comprising of descriptive statistics and budgetary analysis. Descriptive statistics such as percentages, frequency distribution, mean and tabulation were used to describe the socioeconomic characteristics of respondents, the pattern of agrochemical inputs used and the output level of agrochemical users. In turn, budgetary techniques such as gross margin analysis were used to examine the income benefit of pesticide users. The profitability ratio was used to examine the profitability of the crop farming enterprise of agrochemical users.

\section{MODEL SPECIFICATION}

\section{Gross margin analysis}

Following Olukosi and Erhabor (1988), farm budget was estimated on a per-hectare basis and specified as:

Gross Margin $=$ Total Revenue $(\mathrm{TR})-$ Total Variable Cost (TVC)

$$
\begin{gathered}
\mathrm{TR}=P_{\mathrm{y}} \cdot Y \\
\mathrm{TVC}=P_{\mathrm{x}} \cdot X
\end{gathered}
$$

where:

$$
\begin{aligned}
& P_{\mathrm{y}}-\text { unit price of output } \\
& Y-\text { quantity of output } \\
& P_{\mathrm{x}} \text { - unit price of variable input } \\
& X \text { - quantity of variable inputs. }
\end{aligned}
$$

The profitability ratio was estimated as:

$$
\text { Profitability ratio }=\frac{\text { Gross Margin per hectare }}{\text { Variable cost }}
$$

In order for an enterprise to be profitable, the ratio should be greater than zero (Amaza, 1991).

\section{RESULTS AND DISCUSSION}

Table 1 shows that most small-scale farmers in the study area are male $(82.64 \%)$, married $(71.53 \%)$ with a mean age of 31 years. This implies that males are the dominant gender involved in small-scale farming in the study area, and may have access to family labor which participates actively in farming activities.

This result is in line with the findings of Lawal et al. (2014) who posited that small-scale farmers in similar cultural settings are mostly male. Also, Alabi et al. (2014) reported that the mean age of small-scale farmers is between 35 and 45 years, although in this study it is quite smaller. Table 1 also reveals that the majority of small-scale farmers in the study area are edu-

\begin{tabular}{|c|c|c|}
\hline Characteristic & Frequency & Percentage \\
\hline 1 & 2 & 3 \\
\hline \multicolumn{3}{|l|}{ Gender } \\
\hline Male & 119 & 82.64 \\
\hline Female & 25 & 17.36 \\
\hline Total & 144 & 100 \\
\hline \multicolumn{3}{|l|}{ Age } \\
\hline $11-20$ & 17 & 11.81 \\
\hline $21-30$ & 57 & 39.58 \\
\hline $31-40$ & 42 & 29.17 \\
\hline Above 40 & 28 & 19.44 \\
\hline Total & 144 & 100 \\
\hline Mean & 31 & \\
\hline
\end{tabular}
cated $(62.5 \%)$, have an average farming experience of 18 years and an average farm size of 0.78 hectare. The implication of this finding is that high levels of literacy may enhance the adoption of innovations.

Table 1. Socioeconomic characteristics of small-scale crop farmers in this study 
Olayinka, A. S., Lawal, A. F., Bwala, M. A., Mohammed, U. H., Sulaiman, A. I. (2019). Economic analysis and pattern of agrochemicals use among smallholder crop farmers in Edu Local Government Area of Kwara State. J. Agribus. Rural Dev., 2(52), $157-163$. http://dx.doi.org/10.17306/J.JARD.2019.01161

Table 1 cont.

\begin{tabular}{|c|c|c|}
\hline 1 & 2 & 3 \\
\hline \multicolumn{3}{|l|}{ Marital status } \\
\hline Single & 34 & 23.61 \\
\hline Married & 103 & 71.53 \\
\hline Widow/widower & 7 & 4.86 \\
\hline Total & 144 & 100 \\
\hline \multicolumn{3}{|l|}{ Education level } \\
\hline None & 54 & 37.50 \\
\hline Primary & 31 & 21.53 \\
\hline Secondary & 25 & 17.36 \\
\hline Tertiary & 31 & 21.53 \\
\hline Quranic & 3 & 2.08 \\
\hline Total & 144 & 100 \\
\hline \multicolumn{3}{|l|}{ Farming experience } \\
\hline $1-10$ & 36 & 25.00 \\
\hline $11-20$ & 54 & 37.50 \\
\hline $21-30$ & 38 & 26.39 \\
\hline Above 30 & 16 & 11.11 \\
\hline Total & 144 & 100 \\
\hline Mean & & \\
\hline \multicolumn{3}{|l|}{ Farm size } \\
\hline$<0.5$ & 42 & 29.17 \\
\hline $0.5-1$ & 48 & 33.33 \\
\hline Above 1 & 54 & 37.50 \\
\hline Total & 144 & 100 \\
\hline Mean & & \\
\hline \multicolumn{3}{|l|}{ Family size } \\
\hline $1-5$ & 28 & 19.44 \\
\hline $6-10$ & 20 & 13.89 \\
\hline $11-15$ & 39 & 27.08 \\
\hline Above 15 & 57 & 39.59 \\
\hline Total & 144 & 100 \\
\hline Mean & 12 & \\
\hline
\end{tabular}

Source: field survey, 2018.

\section{Pattern of agrochemical use by small-scale crop farmers}

The pattern of agrochemical use by small-scale farmers was examined based on the type of agrochemicals used, time of application, adherence to safety instructions, reason for non-adherence to safety instructions, disposal of agrochemical containers, agrochemicals storage method, addition of other material before application, and reasons for adding the material.

Table 2 shows that herbicides are most used of all agrochemicals $(80 \%)$ in the study area. The result reveals that majority of the sampled farmers $(51.30 \%)$ apply herbicides both before and after crops emerge. This indicates that farmers have knowledge of both selective and non-selective pesticides. A large proportion of farmers $(54 \%)$ do not wear protective clothing while majority (78\%) either eat, drink or smoke when handling agrochemicals, which is contrary to instructions on the handling and use of pesticides. Many of these chemicals are toxic, and exposure to and inhaling them can endanger human health. This result is in line with that of Kamel and Hoppin (2004) who found that most farmers in the developing world are not aware of health hazards posed by agrochemicals. The reason why most $(47.20 \%)$ farmers deviate from safety instructions is that

Table 2. Distribution of crop farmers by pattern of agrochemicals use

\begin{tabular}{lcc}
\hline \multicolumn{1}{c}{ Pattern } & Frequency & Percentage \\
\hline \multicolumn{1}{c}{1} & 2 & 3 \\
\hline Type of agrochemical used & 120 & 80.00 \\
\hline Herbicides & 21 & 14.00 \\
Insecticides & 19 & 6.00 \\
Fungicides & & \\
\hline Time of herbicide application & 16 & 10.70 \\
\hline Before crop emergence & 57 & 38.00 \\
After crop emergence & 77 & 51.30 \\
Both before and after crop emergence & & \\
\hline Safety instructions & 69 & 46.00 \\
\hline Do wear protective clothing & 81 & 54.00 \\
Do not wear protective clothing & 117 & 78.00 \\
Eating when handling agrochemicals & &
\end{tabular}



cals use among smallholder crop farmers in Edu Local Government Area of Kwara State. J. Agribus. Rural Dev., 2(52), 157-163. http://dx.doi.org/10.17306/J.JARD.2019.01161

Table 2 cont.

\begin{tabular}{|c|c|c|}
\hline 1 & 2 & 3 \\
\hline \multicolumn{3}{|l|}{$\begin{array}{l}\text { Reasons for deviation from safety } \\
\text { instruction* }\end{array}$} \\
\hline Cannot read and understand & 83 & 26.60 \\
\hline Protective materials are too costly & 62 & 19.87 \\
\hline Materials are not readily available & 20 & 6.41 \\
\hline Instructions are not important & 147 & 47.12 \\
\hline Total & 312 & \\
\hline \multicolumn{3}{|l|}{ Disposal of agrochemical containers* } \\
\hline Used for beverage & 138 & 39.43 \\
\hline Burnt & 37 & 10.57 \\
\hline Buried & 42 & 12.00 \\
\hline Left on farm & 47 & 13.43 \\
\hline Dumped in open space & 86 & 24.57 \\
\hline Total & 350 & \\
\hline \multicolumn{3}{|l|}{ Agrochemicals storage habit* } \\
\hline Store & 43 & 20.57 \\
\hline House & 119 & 56.94 \\
\hline Farm & 31 & 14.83 \\
\hline Anywhere & 16 & 7.66 \\
\hline Total & 209 & \\
\hline \multicolumn{3}{|l|}{$\begin{array}{l}\text { Addition of other materials before } \\
\text { calibration* }\end{array}$} \\
\hline Salt & 13 & 4.04 \\
\hline Detergents & 43 & 13.35 \\
\hline Diesel & 34 & 10.56 \\
\hline Others & 24 & 7.45 \\
\hline Do not add any material & 208 & 64.60 \\
\hline Total & 322 & \\
\hline \multicolumn{3}{|l|}{ Reasons for adding the materials* } \\
\hline To make it more effective & 61 & 20.00 \\
\hline To increase quantity & 24 & 7.87 \\
\hline For both effectiveness and quantity & 22 & 7.21 \\
\hline No reasons & 198 & 64.92 \\
\hline Total & 305 & \\
\hline
\end{tabular}

Source: field survey, 2018.

*Multiple responses existed. they feel the instructions are not important, meaning that the farmers are ignorant of the safety instruction. Reasonable numbers of the sampled farmers $(39.43 \%)$ used pesticide containers for beverage after use. This habit of disposal is very dangerous to health, especially if the containers are not properly cleaned and sterilized. The study also reveals that majority (56.94\%) of the respondents store pesticides in their living quarters.

The implication is that a long exposure to these chemicals may result in diseases as reported by WHO (2000). This result is in contrast with the findings of (Tijani, 2006) who reported that majority of the farmers place agrochemicals in a store. Reasonable numbers of farmers $(35.40 \%)$ do add material to agrochemicals before application with no reason for the act.

\section{Impact of agrochemicals on outputs and incomes of small-scale farmers}

Arable crop farmers in the study area cultivated maize and millet in mixed cropping on a piece of land while rice and cowpea were cultivated in mono-cropping. Table 3 reveals the average outputs obtained by users of agrochemical inputs. The table shows that cowpea gives the highest output per hectare.

Table 3. Distribution of outputs among users and non-users of agrochemicals

\begin{tabular}{lc}
\hline \multicolumn{1}{c}{ Crops } & Average outputs of users $(\mathrm{kg} / \mathrm{ha})$ \\
\hline Maize & 960 \\
Millet & 800 \\
Rice & 942 \\
Cowpea & 1022 \\
\hline
\end{tabular}

Source: field survey, 2018.

\section{Gross margin analysis for users of agrochemical inputs}

Table 4 shows that labor costs had a large contribution to total variable costs, with a value of USD 448.02, i.e. ca. $37.21 \%$ (hired and family labor). Rice crops give the highest revenue to small-scale farmers in the study area, representing $40.39 \%$ of revenue earned. The Table also reveals that average total variable costs were USD 1,203.71 while the total revenue recorded was USD 2,673.66 per hectare. Thus, gross margin (GM) 
Olayinka, A. S., Lawal, A. F., Bwala, M. A., Mohammed, U. H., Sulaiman, A. I. (2019). Economic analysis and pattern of agrochemicals use among smallholder crop farmers in Edu Local Government Area of Kwara State. J. Agribus. Rural Dev., 2(52), $157-163$. http://dx.doi.org/10.17306/J.JARD.2019.01161

Table 4. Gross margin analysis for users of agrochemical inputs (per hectare)

\begin{tabular}{llcrc}
\hline \multicolumn{1}{c}{ Variable inputs } & \multicolumn{1}{c}{ Quantity } & Unit cost (USD) & Total cost (USD) & Percentage \\
\hline A variable costs & & & & \\
Pesticides & 32.68 liters & 3.59 & 117.43 & 9.76 \\
Transportation & - & - & 338.79 & 28.15 \\
Storage & - & - & 96.22 & 7.99 \\
Packaging & - & - & 29.27 & 2.43 \\
Hired labor & 4058 man-days & & 129.32 & 10.74 \\
Family labor & 10021 man-days & & 318.70 & 26.47 \\
Seeds & & & 173.98 & 14.46 \\
Total variable cost & & & $1,203.71$ & 100 \\
B Revenue & $\mathrm{kg}$ & & & 11.85 \\
Maize & 960 & 0.33 & 316.80 & 10.17 \\
Millet & 800 & 0.34 & 272.00 & 40.52 \\
Rice & 942 & 1.15 & $1,083.30$ & 37.46 \\
Cowpea & 1022 & 0.98 & $1,001 . .56$ & 100 \\
Total revenue & & & $2,673.66$ & $1,469.95$ \\
Gross margin (B-A) & & & 1.22 & \\
Profitability ratio & & & & \\
\hline
\end{tabular}

Source: field survey, 2018.

A total gross margin of USD 1,469.95 was received by small-scale farmers using agrochemical inputs.

was USD 1,469.95. The profitability ratio was found to be 1.22. This implies that small-scale farmers using agrochemicals earned a profit of USD 1.22 which is ca. $122 \%$ of invested funds. This result is supported by the finding of Bhandari (2014) who reported that agrochemicals are considered as a powerful weapon or magic bullets in the developing countries in order to enhance the profitability and productivity of agriculture.

\section{CONCLUSION AND RECOMMENDATIONS}

This study found that most small scale-farmers in the study area used agrochemical inputs, and that safety instructions were not adhered to by majority of farmers in the study area. The farmers' inability to comply with safety instructions was as a result of inadequate knowledge of health implications of agrochemicals. The study also revealed that the use of agrochemical inputs improves crop yields, thereby increasing farming incomes in the study area. Therefore, this study concludes that the use of agrochemical inputs increases the profitability of arable crops enterprise in the study area. Furthermore, safety instructions regarding agrochemical use are not adhered to. The study therefore recommends that programs on agrochemical usage be initiated to educate farmers.

\section{SOURCE OF FINANCING}

Self-financed.

\section{REFERENCE}

Alabi, O. O., Lawal, A. F., Coker, A. A., Awoyinka, Y. A. (2014). Probit Model Analysis of Smallholder's Farmers Decision to Use Agrochemical Inputs In Gwagwalada and 
Kuje Area Councils of Federal Capital Territory, Abuja Nigeria. Int. J. Food Agric. Econ., 2(1), 85-94.

Alamu, J. F., Coker, A. A. (2005). Sustainability of Fadama Farming in Northern Nigeria. The Case of Kaduna State. Samaru J. Agric. Res., 21, 42-50.

Albert, H. (1989). Why organic manure are better than chemical fertilizer. J. Agric. 1(19), 53-59.

Amaza, P. S (1991). Economics Analysis of Cereal/Legumes Cropping by Peasant

Andrew, W. (2008). http://disaster.itas.uft.edu/agrochemicalsecurity.htmagrow (538):5 retrieved 5th Dec. 2011.

Bhandari, G. (2014). An Overview of Agrochemicals and Their Effects on Environment in Nepal. Appl. Ecol. Env. Sci., 2(2), 66-73.

Fleisher, G. (2006). Agricultural chemical - how much input is required, how much is too much. Agric. Rural Sociol. Dev., 1, 51-53.

Kamel, F., Hoppin, J. A. (2004). Association of pesticide exposure with neurologic dysfunction and disease. Env. Health Persp., 112(9), 950-958.

Larry, J. K. (2012). Dry-Season Farming and Agriculture Misuse in Upper East Region of Ghana; Implication and Way Forward. J. Agric. Food Env. Sci., 5(1), 1-9.
Lawal, A. F., Liman, A., Ibrahim, D. A., Yusuf, L. T. (2014). Technical Inefficiency and Sustainability of Rice Production in the Fadama of Niger State, Southern Guinea Savannah, Nigeria. India J. Life Sci., 3(2), 15-25.

National Population Commission (2006). Human Population Figures of Cencus in Nigeria.

Olukosi, J. O., Erhabor, P. O. (1988). Introduction to farm management economics. Ajitab Publ. Zair, 35-36.

Seattle, P. I. (2008). The Lowdown On Top Soil: It Is Disappearing. Small And Medium Enterprise And Finding In Nigeria.

Tijani, A. A. (2006). Pesticide Use Practice and Safety Issues: the case study of cocoa farmers in Ondo State, Nigeria. A working paper.

WHO (2000). Factsheet 94 Malaria.

WHO (2008). Public Health and Enviroment and Qualifying Environmental Health Impact. Retrieved from: www. WHO.in/topical environmental health/en/

Vissoh, P. V., Gbehounou, G., Ahanchede, A., Kuyper, T. W., Roling, N.G. (2004). Weeds as Agricultural Constraint to Farmers in Benin: Results of a Diagnostic Study. NJAS, 52(3/4), 305-329. 